\title{
Association of the plasminogen activator inhibitor-1(PAI-1) gene 4G/5G promoter polymorphism in Buerger's disease (Tromboangiitis obliterans)
}

\author{
Sinasi Manduz ${ }^{1}$, Nurkay Katrancioglu' ${ }^{1}$, Oguz Karahan ${ }^{1}$, Oztürk Ozdemir ${ }^{2 *}$ \\ ${ }^{1}$ Department of Cardiovascular Surgery, Faculty of Medicine, Cumhuriyet University, Sivas, Turkey \\ ${ }^{2}$ Department of Medical Genetics, Faculty of Medicine, Cumhuriyet University, Sivas and University of COMU, Faculty of Medicine, \\ Canakkale, Turkey; *Corresponding Author: ozdemir615@yahoo.com
}

Received 3 January 2010; revised 26 January 2010; accepted 27 January 2010.

\begin{abstract}
Thromboangiitis obliterans (TAO) is an unusual tobacco-associated vasculopathy that is a nonatherosclerotic inflammatory disorder of unknown etiology that affects small and mediumsized vessels of the extremities. The single guanosine nucleotide deletion/insertion polymorphism $(4 \mathrm{G} / 5 \mathrm{G})$ at $-675 \mathrm{bp}$ in promoter region of the PAI-1 gene is the major genetic determinant of PAl-1 expression. Plasma PAI-1 level is higher in people with the homozygous $4 \mathrm{G}$ genotype than in those with the 5G/5G genotype and renders higher transcription activity. The aim of this study was to determine the status and the role of PAI-1 gene 4G/5G promoter polymorphism in patients with Buerger's disease (Thromboangiitis obliterans-TAO). The current case-control study included 30 consecutive patients with Buerger's disease (mean age $42.9 \pm$ 14.3 years, 28 men and 2 women), and 30 healthy volunteers (mean age $40.9 \pm 4.79$ years, 27 men and 3 women) between January 2006 and September 2009. Patients and control cases were genotyped for the $4 \mathrm{G} / 5 \mathrm{G}$ polymorphism using the multiplex PCR based stripassay reverse hybridisation technique. It was found that heterozygote PAl-1 gene polymorphisms $(p<0.05)$ was significantly more frequent in patients with TAO in the current results. There was a significant difference in genotype distribution between the two groups $(P<0.001)$. The $4 G$ allele occurred more frequently in the patient group of heavy smokers $(P=0.05)$. The current study shows the higher prevalence of of $4 \mathrm{G}$ allele in TAO patients in Sivas population means gene may predispose to TAO.
\end{abstract}

Keywords: Thromboangiitis Obliterans; Genetic
Polymorphisms; PAI-1

\section{INTRODUCTION}

In 1908 Buerger suggested the name thromboangiitis obliterans (TAO) for a disease of the peripheral arteries which he had studied in eleven lower limbs amputated for "presenile spontaneous gangrene" [1]. TAO (Buerger's syndrome) is an unusual tobacco-associated vasculopathy that is a nonatherosclerotic inflammatory disorder of unknown etiology that affects small and medium-sized vessels of the extremities [1-3]. Etiopathogenesis of disease could not be evenly revealed. Researchers think that tobacco is rolled for starting and progressing of disease and by the way genetic factors, hipercoagulability, endothelium function and immune mechanisms etc. are suspicious factors that enrolled such as tobacco $[1,2,4,5]$. For example HLA-9 and HLA-B5 was excessively documented in patients. This may sign that genetic factors likely play a role [5].

Highly cellular thrombus occludes much of the lumen and lymphocytes, giant cells, fibrous hyperplasia, intimae thickness have seen around vaso-vasorums in histological investigation of vessel that affected by TAO [5]. A highly cellular thrombus occludes much of the lumen. A multinucleate giant cell and microabscess are present within the thrombus [5].

Both genetic and thrombotic events, reminds that prothrombotic gene deletions might act a part in this disorder. Prothrombotic genes detected significantly in some studies about TAO [6]. Plasminogen is one of mediators of fibrinolysis that synthesized in the liver and then circulates in plasma and other extracellular fluids. This respect presents in all tissues [7]. Urokinase-type plasminogen activator (uPA) and the tissue-type PA (tPA) are two regulative enzymes that directed the modulation of plasminogen to plasmin. The enzymatic activity of uPA can be inhibited plasminogen activator inhibitor 
(PAI) -1 and PAI-2 [8]. PAI-1 is a major inhibitor of the fibrinolytic system. The PAI-1 gene polymorphism is known as a deletion/insertion of $\mathrm{G}$ base $(5 \mathrm{G} / 4 \mathrm{G})$ in codon -675 and the major genetic determinant of PAI-1 expression. The 4G allele renders higher transcription activity than the PAI-1 promoter with the $5 \mathrm{G}$ allele in stimulated MCs [9]. The polymorphic PAI-1 gene is a member of plasminogen cascade with an inhibitory role in plasmin activation by response to cytokines, hormones and many growth factors. Isordila et al., claimed that the $4 \mathrm{G}$ allele is an independent risk factor for acute myocardial infarction in young patients, as are smoking, hypertension and a family history of inherited cardiovascular disease [9]. It was aimed to find out the possible role of polymorphic $5 \mathrm{G} / 4 \mathrm{G}$ alleles of PAI- 1 gene in $\mathrm{TAO}$ in the current results.

\section{MATERIAL AND METHOD}

Thirty patients diagnosed with TAO at 1998 to 2009 in our clinic were included the study. Total genomic DNA from peripheral blood samples were used for each patient and control for $4 \mathrm{G} / 5 \mathrm{G}$ polymorphism in PAI-1 gene. Control group was composed of healthy individuals who had no vascular complaints.

Clinical diagnosis of TAO was made according to criteria of Shionoya and defined as fallows; a history of smoking, disease on set before the age of 50 years, infrapopliteal arterial occlusions, upperlimb involvement or phlebitis migrans, and the absence of atherosclerotic risk factors other than smoking. In Doppler ultrasound of cases, the decreased arterial flow pattern was also revealed. Because of this arteriography was applied all cases. In arteriography, arterial occlusion and corkscrew collaterals revealed typically.

Mutation Analysis: Two ml of peripheral blood-EDTA samples were used for total genomic DNA isolation (Invitek, Berlin, Germany). Multiplex PCR-based reverse hybridisation stripAssay technique (Vienna Lab, Labordiagnostika $\mathrm{GmbH}$, and Vienna, Austria) was used for mutation analysis (ProfiBlot T48, Tecan, Switzerland). Genotyping of PAI-1 gene was made and compared to the control group individuals.

Statistical Analysis: The SPSS software (ver; 14.0) was used for evaluation of data, $\chi^{2}$-test (chi-square) was used to compare the significance of the differences between groups. The test of importance between the mean of two groups was used for accordance of two groups and margin of error was approved to as 0.05 . Furthermore appropriateness of groups was evaluated with importance test of difference of between two groups.

\section{RESULTS}

The informed consents of the patients were also obta- ined. 30 TAO patients ( 28 males, 2 females and mean ages was $42.9 \pm 14.3$ years) and 30 healthy controls ( 27 males, 3 females and mean ages was $40.9 \pm 4.79$ years) were included in the current study. Two groups were similar regarding age and sex distribution $[(\mathrm{t}=0.69) ; \mathrm{P}=$ $0.487 ; p>0.05]$. Twenty nine $(97 \%)$ cases had a history of smoking in TAO group and $22(73 \%)$ cases had a history of smoking in control group. Detection of etiopathogenesis is important for meticulous care of these patients. Homozygous $4 \mathrm{G} / 4 \mathrm{G}$ profile was $7 \%$ for TAO and $4 \%$ for control individuals. The homozygous wide type $5 \mathrm{G} / 5 \mathrm{G}$ genotype was $10 \%$ in patients with TAO and $53 \%$ in healthy controls (Table 1). Heterozygote mutation of $4 \mathrm{G} / 5 \mathrm{G}$ profile was detected in $25(83.3 \%)$ patients with TAO and $13(43.3 \%)$ control subjects. The current results indicate that the $4 \mathrm{G} / 5 \mathrm{G}$ gene polymorphism of PAI-1 is significantly associated with TAO while 4G/4G type may probably be an important hereditary risk factor as well. We found that heterozygote PAI gene polymorphisms $(p<0.05)$ were significantly more frequent in patients with TAO. We detected PAI-1 5G/ 4G polymorphism was significantly higher in TAO group $(\mathrm{p}=0.001)$ (Table 1 and Figure 1). Most possibly the $4 \mathrm{G} / 5 \mathrm{G}$ gene polymorphism for PAI-1 may be an acceptable risk factor of TAO.

Table 1. The percantages of polymorphic alleles $(5 \mathrm{G} / 4 \mathrm{G})$ for PAI-1 gene in the current TAO and control groups.

\begin{tabular}{ccccc}
\hline GROUP & \multicolumn{5}{c}{ ALTERNATIVE GENOTYPES FOR PAI-1 } \\
& \multicolumn{4}{c}{ GENE } \\
\hline & $\mathbf{4 G / 4 G}$ & $\mathbf{4 G / 5 G}$ & $\mathbf{5 G / 5 G}$ & $\begin{array}{c}\text { Total } \\
\text { (n-\%) }\end{array}$ \\
$\begin{array}{c}\text { TAO } \\
(\mathbf{n - \% )}\end{array}$ & $2-7$ & $25-83$ & $3-10$ & $30-100$ \\
$\begin{array}{c}\text { Control } \\
(\mathbf{n - \% )}\end{array}$ & $1-4$ & $13-43$ & $16-53$ & $30-100$ \\
$* \mathbf{P}$ & $\mathbf{0 . 0 5}$ & 0.001 & 0.001 & \\
\hline
\end{tabular}

$* \mathrm{p}<0.05$ is significant

PAI-1 4G/5G

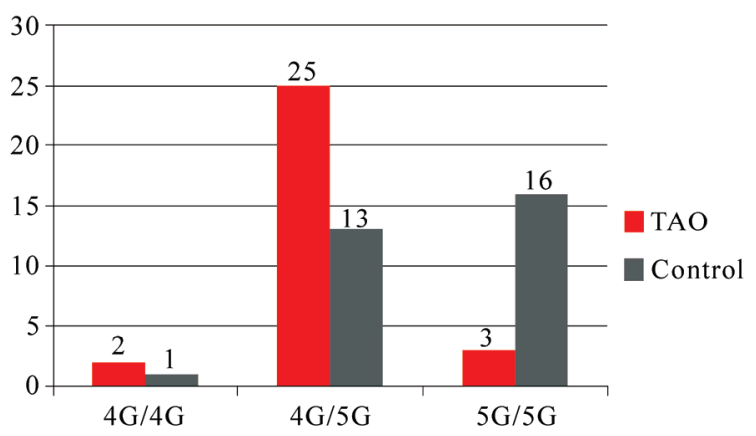

Figure 1. Shows the barr diagram of alternative $5 \mathrm{G} / 4 \mathrm{G}$ alleles of PAI-1 gene in TAO and control groups. 


\section{DISCUSSIONS}

Some association has been suggested between Buerger's disease (TAO) and other syndromes but there is still no consensus about diagnostic criteria. TAO is a nonatherosclerotic inflammatory disorder of unknown etiology that affects small and medium-sized vessels of the extremities [1-3]. It is usually present at less than 40 years old in male sex. However, last studies show that this disease can be appears in smoking females [5]. In our study, there were 28 (93\%) males, 2 (7\%) females' cases in TAO group and the mean age was $42.9 \pm 14.3$ years. On the other hand, control group was consisted of 27 (90\%) males, $3(10 \%)$ females. Additionally 29 (97\%) subjects had smoking history in TAO group and $22(73 \%)$ in control group. TAO is diagnosed and treated with difficulty because of elusive etiology (10]. There is no sufficient knowledge about the other risk factors and predisposing conditions in the literature $[11,12]$. It was documented that there was a strongly relationship between TAO and HLA-9 and HLA-B5. This situation remind to genetical predisposition can be rolled in background of this disorder [5]. The effected vessel was filled with the thrombus formation in microscopical scanning [5]. Prothrombotic risk factors were observed in this disease because of genetical suspicions and thrombotic findings [6]. The $4 \mathrm{G} / 5 \mathrm{G}$ alleles in PAI-1 and MTHFR C677T gene polymorphisms may help to identify the couples at risk for recurrent pregnancy loss [13]. Abboud et al. showed that the risk of myocardial infarction (MI) was notably high in $4 \mathrm{G}$ and $-844 \mathrm{~A}$ carriers with elevated plasma PAI-1 and were associated with reduced tPA levels [14]. PAI-1 concentration increases because of the $4 \mathrm{G}$ deletion of $675^{\text {th }}$ promoter region of PAI gene. Therefore, fibrinolytic activity is reduces and predisposing thrombotic events are increases [15]. It was demonstrated that all alone or combined effect of this gene deletion was impacted deep venous thrombosis (DVT), in studies [16]. Choudhury and friends detected that the free PAI-1 levels can be significant venous occlusion in TAO patients [17]. This gene mutation accused in Turkish DVT patients [18]. A meta-analyze signs to $4 \mathrm{G} / 4 \mathrm{G}$ genotype was $20 \%$ folds increased of myocardial infarction risk that have included 9 studies [19]. Another meta-analyze points to each $4 \mathrm{G}$ allele was slightly increased of myocardial infarction risk that have included 37 studies [20]. Recently another meta-analyze that included 17 studies points that there was average relation ship between $4 \mathrm{G}$ allele and venous thromboemboli in subjects which have no genetical and acquired prothrombotic risk factors [21]. In our study we detected PAI-1 4G/5G deletion in $25(83 \%)$ subjects in TAO group (Figure 1). Although there were 13 (43\%) subjects detected with PAI-1 4G/5G deletion in control group. Evaluation of the difference between two groups was statistically significant $(\mathrm{p}=0.001)$ (Table 1$)$. Analysis of etiopathogenesis of TAO disease has importance for loss of extremity and labor force by reason of this disease and these results should be verified by larger population studies. In view of previous and current results, there is a clear need to redefine the diagnostic algorithm and the criteria for diagnosing TAO (Buerger's disease).

In conclusion, our study revealed the presence of suspicious relationship between TAO and PAI-1 gene polymorphism. However this is a pilot study including limited number of subjects and it must be supported with large cohort studies. In addition, it is believed that the current results could be helpful for analysis of etiopathogenesis of TAO in the future studies. Additionally, analyses of etiopathogenesis of the TAO disease have importance for prevention of potential losses of extremity and labor force caused by this disease.

\section{REFERENCES}

[1] Buerger, L. (1952) Thrombo-angiitis obliterans: A study of the vascular lesions leading to presenile spontaneous gangrene. American Journal of Medicine, 13(5), 526532.

[2] Brodmann, M., Renner, W., Stark, G., Winkler, M., Pabst, E., Hofmann, C. and Pilger, E. (2000) Prothrombotic risk factors in patients with thrombangitis obliterans. Thrombosis Research, 99(5), 483-486.

[3] Cooper, L.T., Tse, T.S., Mikhail, M.A., Mcbane, R.D., Stanson, A.W. and Ballman, K.V. (2004) Long-term survival and amputation risk in thromboangiitis obliterans (Buerger's disease). Journal of the American College of Cardiology, 44(12), 2410-2411.

[4] Taşoğlu, I., Hanedan, O. and Ulus, A.T. (2008) Thromboangiitis obliterans (buerger hastalığı). Turkiye Klinikleri Journal of General Surgery Special Topics, 1(3), 1525.

[5] Szuba, A. and Cooke, J.P. (1998) Thromboangiitis obliterans. An update on Buerger's disease. Western Journal of Medicine, 168(4), 255-260.

[6] Özen, F., Manduz, Ş., Katrancioğlu, N., Karahan, O., Köksal, B. and Özdemir, Ö. (2009) Tromboanjiitis obliterans hastalarında protrombotik gen polimorfizminin rolü turkiye klinikleri. Journal of Cardiovascular Science, 21(2), 160-164.

[7] Isserhoff, R.R. and Rifkin, D.B. (1983) Plasminogen is present in the basal layer of the epidermis. Journal of Investigative Dermatology, 80, 297-299.

[8] Herouy, Y., Trefzer, D., Hellstern, M.O., Stark, G.B., Vansche1dt, W., Schoè, P.F.E. and Norgauer J. (2000) Plasminogen activation in venous leg ulcers. British Journal of Dermatology, 143(5), 930-936.

[9] Isordia-Salas, I., Leaños-Miranda, A., Sainz, I.M., ReyesMaldonado, E. and Borrayo-Sánchez, G. (2009) Association of the plasminogen activator inhibitor-1 gene $4 \mathrm{G} / 5 \mathrm{G}$ polymorphism with ST elevation acute myocardial infarction in young patients. Revista Española de Cardiología, 62(4), 365-372. 
[10] Foley, S. and Gibbs, H. (2008) Muir painful digital infarction in a male smoker treated as Buerger's disease. Australasian Journal of Dermatology, 49(2), 94-97.

[11] Stammler, F., Diehm, C., Hsu, E., Stockinger, K. and Amendt, K. (1996) The prevalence of hyperhomocysteinemia in thrombangitis obliterans. Does homocsteine play a role pathogenetically? Deutsche medizinische Wochenschrift, 121(46), 1417-1423.

[12] Chenl, Z., Takahashi, M., Naruse, T., Nakajima, T., Chen, Y.W., Inoue, Y., Ishikawa, I., Iwail, T. and Kimura, A. (2007) Synergistic contribution of CD14 and HLA loci in the susceptibility to Buerger disease. Human Genetics, 122(3-4), 367-372.

[13] Yenicesu, G.I., Cetin, M., Ozdemir, O., Cetin, A., Ozen, F., Yenicesu, C., Yildiz, C. and Kocak, N. (2009) A prospective case-control study analyzes 12 thrombophilic gene mutations in turkish couples with recurrent pregnancy loss. American Journal of Reproductive Immunology, 63(2), 126-136.

[14] Abboud, N., Ghazouani, L., Saidi, S., Ben-Hadj-Khalifa, S., Addad, F., Almawi, W.Y. and Mahjoub, T. (2010) Association of PAI-1 4G/5G and -844G/A gene polymorphisms and changes in PAI-1/tissue plasminogen activator levels in myocardial infarction: A case-control study. Genetic Testing and Molecular Biomarkers, 14(1), 2327.

[15] Francis, C.W. (2002) Plasminogen activator inhibitor-1 levels and polymorphisms. Archives of Pathology \& Laboratory Medicine, 126(11), 1401-1404.

[16] Akar, N., et al. (2000) Effect of plasminogen activator inhibitor-1 4G/5G polymorphism in turkish deep vein thrombotic patients with and without FV1691 G-A. Thrombosis Research, 97, 227-230.

[17] Choudhury, N.A., Pietraszek, M.H., Hachiya, T., Baba, S., Sakaguchi, S., Takada, Y. and Takada, A. (1992) Plasminogen activators and plasminogen activator inhibitor 1 before and after venous occlusion of the upper limb in thromboangiitis obliterans (Buerger's disease). Thrombosis Research, 66(4), 321-329.

[18] Eroglu, A., Ulu, A. and Akar, N. (2006) Plasminogen activator inhibitor- 1 gene $4 \mathrm{G} / 5 \mathrm{G}$ polymorphism in cancer patients with and without thrombosis. Journal of Thrombosis and Thrombolysis, 22(2), 111-112.

[19] Boekholdt, S.M., Bijsterveld, N.R., Moons, A.H., Levi, M., Büller, H.R. and Peters, R.J. (2001) Genetic variation in coagulation and fibrinolytic proteins and their relation with acute myocardial infarction: A systematic review. Circulation, 104(25), 3063-3068.

[20] Ye, Z., Liu, E.H., Higgins, J.P., Keavney, B.D., Lowe, G.D., Collins, R. and Danesh J. (2006) Seven haemostatic gene polymorphisms in coronary disease: Meta-analysis of 66, 155 cases and 91,307 controls. Lancet, 367(9511), 651658.

[21] Tsantes, A.E., Nikolopoulos, G.K., Bagos, P.G., Rapti, E., Mantzios, G., Kapsimali, V. and Travlou, A. (2007) Association between the plasminogen activator inhibitor-1 4G/5G polymorphism and venous thrombosis. A meta-analysis. Journal of Thrombosis and Haemostasis, 97(6), 907-913. 